\title{
Pengaruh senam terhadap skala insomnia pada lansia di Panti Jompo Karya Kasih Kota Medan
}

\author{
Adnan Akbar Lubis*, Sunny Puspita, Meldawati \\ Fakultas Kedokteran Universitas Prima Indonesia \\ *Korespondensi: adnanakbarlubis05@gmail.com \\ DOI: doi.org/10.1616/jpms.v2i2.1256 \\ (C) 2020 JPMS. All rights reserved
}

\begin{abstract}
Abstrak
Pada lansia, kualitas tidur pada malam hari mengalami penurunan menjadi sekitar $70-80 \%$ sedikit efektif dari usia dewasa. Insomnia adalah ketidakmampuan untuk tidur walaupun ada keinginan untuk melakukannya. Lansia rentan terhadap insomnia karena adanya perubahan pola tidur. Keluhan insomnia mencakup ketidakmampuan untuk tertidur, sering terbangun, ketidakmampuan untuk kembali tidur, dan terbangun pada dini hari. Tujuan penelitian ini adalah untuk mengetahui pengaruh senam terhadap skala insomnia pada lansia di Panti Jompo Karya Kasih Kota Medan. Penelitian ini merupakan penelitian quasi eksperimental. pretest-posttest without control group. Hasil penelitian ini menunjukkan bahwa usia bahwa paling banyak responden berusia 61-70 tahun di Panti Jompo Karya Kasih Medan. Berdasarkan jenis kelamin paling banyak perempuan di Panti Jompo Karya Kasih Medan. Hasil uji analisis dijumpai nilai p 0,001 yang artinya signifikan adanya perbedaan yang signifikan tingka insomnia sebelum dan sesudah dilakukan senam lansia di Panti Jompo Karya Kasih Medan.
\end{abstract}

Kata kunci: Insomnia, kualitas tidur, senam lansia

\begin{abstract}
In the elderly, the quality of sleep at night decreases to around $70-80 \%$, slightly effective from adulthood. Insomnia is the inability to sleep. Elderly vulnerable to insomnia due to changes in sleep patterns. Insomnia complaints regulate the inability to fall asleep, often waking up, the inability to go back to sleep, and waking up in the early hours of the morning. The purpose of this study was to study the interaction of gymnastics on the scale of insomnia in the elderly at the Nursing Home of Karya Kasih in Medan. This research is a quasi experimental research. pretest-posttest without a control group. Research respondents showed research aged 61-70 years at the Nursing Home in Medan Kasih. Nursing Home Work Love Medan. Results of the analysis test were found to be $p$ value 0.001 , which means the significance of significant differences in insomnia levels before and after the elderly gymnastics exercise at the Nursing Home in Karya Kasih Medan.
\end{abstract}

Key words: Insomnia, sleep quality, elderly gymnastics

\section{Pendahuluan}

Lanjut usia merupakan suatu anugerah. Menjadi tua, dengan segenap keterbatasannya, pasti akan dialami oleh seseorang bila ia panjang umur. Di Indonesia, istilah untuk kelompok usia ini belum baku, orang memiliki sebutan yang berbeda-beda. Ada yang menggunakan istilah usia lanjut ada pula lanjut usia. ${ }^{1}$

Data proporsi lanjut usia di dunia diperkirakan mencapai $22 \%$ dari penduduk dunia atau sekitar 2 miliar pada tahun 2020, sekitar $80 \%$ lanjut usia hidup di negara berkembang. Jumlah penduduk di 11 negara anggota World Health Organization (WHO) kawasan Asia Tenggara yang berusia di atas 60 tahun berjumlah 142 juta orang dan diperkirakan akan terus meningkat hingga 3 kali lipat di tahun 2050. Sedangkan jumlah lanjut usia di seluruh dunia dapat mencapai jumlah 1 miliar orang dalam kurun 10 tahun mendatang. ${ }^{2}$

Pada lansia, kualitas tidur pada malam hari mengalami penurunan menjadi sekitar 70$80 \%$ sedikit efektif dari usia dewasa. Insomnia adalah ketidakmampuan untuk tidur walaupun ada keinginan untuk melakukannya. Lansia rentan terhadap insomnia karena adanya perubahan pola tidur. Keluhan insomnia mencakup ketidakmampuan untuk tertidur, sering terbangun, ketidakmampuan untuk kembali tidur, dan terbangun pada dini hari. ${ }^{3}$ 
Menurut American Academy of Family Physicians, manfaat olahraga dapat dirasakan oleh hampir semua lansia. Olahraga teratur dapat memberi efek relaksasi, memperbaiki suasana hati, memperkecil kemungkinan cedera, dan melindungi dari penyakit kronis. Olahraga merupakan salah satu cara penghilang stress yang baik. Aktivitas fisik (olahraga) dapat membantu orang tua menjaga indenpedensi, sembuh dari penyakit dan mengurangi risiko penyakit. Massa otot dan kekuatan tulang dapat ditingkatkan dengan olahraga teratur. Berjalan, berenang, senam, dan bersepeda adalah semua bentuk latihan yang baik yang juga bisa bersosialisasi. Beberapa studi penelitian menunjukan bahwa olahraga teratur mungkin sama efektifnya dengan perawatan lain seperti obat untuk meredakan depresi ringan. ${ }^{4}$

Senam lansia merupakan bentuk peran serta masyarakat lansia dalam upaya mencapai derajat kesehatan yang optimal serta kondisi menua yang sehat dan mandiri. Hasil riset dari Sumedi (2010) tentang pengaruh skala insomnia sebelum dan sesudah dilakukan senam bugar lansia menunjukkan bahwa terdapat perbedaan skala insomnia pada lansia antara sebelum dan sesudah dilakukan senam bugar lansia. Jumlah keseluruhan lansia yang mengalami penurunan skala insomnia adalah 68,75 persen. $^{5}$

Penelitian oleh Darnimala (2015) menyatakan bahwa Hasil dari penelitian ini didapatkan $70 \%$ lansia mengalami insomnia. Angka kejadian insomnia pada lansia tahun 2015 ditempat dilaksanakannya penelitian ini termasuk cukup tinggi sehingga diperlukannya analisis lebih lanjut dan mendalam mengenai hal yang menyebabkan tingginya angka kejadian insomnia pada lansia, karena insomnia sendiri dapat mengganggu lansia dalam menikmati hari tuanya. ${ }^{6}$

Berdasarkan hasil survei pendahuluan di Panti Karya Kasih Kota Medan beberapa di antaranya mengalami insomnia. Hal ini menunjukkan bahwa 75\% lansia di Panti Karya Kasih mengalami insomnia. Hasil wawancara yang dilakukan dengan salah satu petugas. Tanda dan gejala dari insomnia itu sendiri yang sering muncul adalah sulit tidur pada malam hari, mudah marah, depresi, gelisah, maag dan kesulitan untuk memulai tidur. Masalah lain yang mencetuskan insomnia di lingkungan panti adalah perselisihan antar teman dan kebisingan antar teman. Penelitian ini bertujuan untuk mengukur pengaruh senam terhadap skala insomnia pada lansia di Panti Jompo Karya Kasih Kota Medan.

\section{Metode Penelitian}

Penelitian ini merupakan penelitian quasi eksperimental dengan rancangan pretest-posttest without control group. Pada penelitian ini dilakukan eksperimen berupa pemberian perlakuan senam bugar lansia untuk menilai kebugaran melalui pemeriksaan vital sign. Penelitian dilaksanakan di Panti Jompo Karya Kasih Medan dengan sampel penelitian sebanyak 78 orang.

\section{Hasil}

Data umum responden (lihat pada Tabel 1) berisi mengenai usia responden. Paling banyak lansia di Panti Jompo Karya Kasih Medan berkelamin perempuan sebanyak 48 orang $(61 \%)$ dan laki-laki 30 orang (38\%). Lansia paling banyak berusia 61-70 tahun sebanyak 31 orang (39.7\%), yang berusia $71-80$ tahun sebanyak 22 orang (28\%) yang berusia 50-60 tahun sebanyak 18 orang (23\%) dan paling sedikit berusia $>80$ tahun sebanyak 7 orang $(9 \%)$.

Tabel 1. Karakteristik responden

\begin{tabular}{ccc}
\hline & Jumlah (n) & Persentase (\%) \\
\hline Jenis Kelamin & & \\
Laki-Laki & 30 & 38,4 \\
Perempuan & 48 & 61,6 \\
Umur & & \\
$50-60$ & 18 & 23,1 \\
$61-70$ & 31 & 39,7 \\
$71-80$ & 22 & 28,2 \\
$>80$ & 7 & 9 \\
\hline
\end{tabular}


Berdasarkan hasil analisis diketahui nilai signifkansi (sig 2 tailed) sebesar 0,000 (kurang dari 0,05). Dari tabel diketahui nilai mean 9.542, dengan nilai p 0.001. Jadi disimpulkan bahwa ada perbedaan rata-rata antara sebelum dan sesudah intervensi (lihat Tabel 2).
Jika signifikansi $<0,05$ maka kesimpulannya ada perbedaan skor pretest dan post test. Sebaliknya jika signifikansi $>0,05$ maka tidak ada perbedaan antara skor pretest dan skor post test.

Tabel 2. Rata-rata tingkat insomnia sebelum dan setelah mendapatkan intervensi senam lansia

\begin{tabular}{ccccc}
\hline Variabel & Mean & SD & SE & nilai p \\
\hline $\begin{array}{c}\text { Tingkat insomnia sebelum } \\
\text { dilakukan senam - Kualitas } \\
\text { tidur setelah dilakukan senam }\end{array}$ & 9.542 & 1.888 & 0.385 & 0.001 \\
\hline
\end{tabular}

\section{Pembahasan}

Insomnia pada lansia disebabkan oleh beberapa faktor, salah satunya menurut Nugroho (2010) adalah lingkungan fisik, di mana lingkungan fisik tempat tidur seseorang berpengaruh terhadap kemampuan seseorang tertidur misalnya suara, pencahayaan, suhu ruangan kamar, kebisingan. ${ }^{7}$ Lingkungan fisik di panti tersebut menyebabkan ketidaknyamanan tidur karena fasilitas yang ada disana kurang dapat mendukung lansia untuk memenuhi kebutuhan istirahat tidur lansia. Hal ini penulis amati saat melakukan penelitian terdapat jendela kamar yang jarang dibuka dan tidak bisa dilewati oleh sinar matahari, akibatnya ruangan terasa pengap. Kamar yang pengap akan mengakibatkan lansia gerah, karena tidak adanya pergantian udara dari luar ke dalam ataupun sebaliknya.

Selain itu juga tempat tidur yang tidak memiliki pagar turut mendukung lansia tersebut tidak bisa tidur karena lansia khawatir dan takut terjatuh. Kekhawatiran lansia muncul saat akan memulai tidur, mereka berfikiran kalau saat mereka tidur tiba-tiba mereka terjatuh dari tempat tidurnya. Hal inilah yang menyebabkan mengapa insomnia lansia berada pada kategori sedang. Selain faktor di atas, insomnia pada lansia juga dipengaruhi oleh usia responden.

Menurut pernyataan Luce dan Sega dalam Sumedi (2010) mengatakan bahwa keluhan terhadap gangguan tidur akan meningkat seiring dengan bertambahnya usia. ${ }^{5}$ Bertambahnya usia akan berpengaruh terhadap penurunan hormonal, salah satunya adalah hormon melatonin. Hormon ini berperan penting saat malam hari, sekresi hormon melatonin berfungsi menimbulkan rasa kantuk pada lansia. Apabila hormon ini sekresinya berkurang secara otomatis lansia akan mengalami penurunan keinginan untuk tidur. Secara tidak langsung akan berdampak pada penurunan kualitas tidur, sehingga lansia akan mudah terbangun dan tidak dapat kembali tidur dengan pulas. ${ }^{8}$

Menurut Hidayat (2012) bahwa insomnia lebih sering terjadi pada kalangan lansia wanita, karena lebih rentan mengalami kecemasan dan stress. ${ }^{9}$ Berdasarkan jenis kelamin responden, didapatkan hasil bahwa seluruh responden berjenis kelamin perempuan (100\%). Teori ini juga didukung oleh pendapat Susanti (2013) yang mengatakan bahwa wanita lebih beresiko mengalami insomnia karena terjadi penurunan kadar homone estrogen dan progesteron. Penurunan hormon ini terjadi saat wanita memasuki masa menopouse. Diketahui bahwa semua responden di Panti Werdha tersebut merupakan kelompok wanita yang sudah memasuki masa menapause. Kedua hormon ini memang sangat mempengaruhi suasana hati ataupun stres. ${ }^{10}$

Oleh sebab itu masa-masa menopause memang rentan terhadap datangnya berbagai masalah-masalah, khusunya masalah psikologis, didukung juga karakter wanita yang memang lebih cenderung memiliki sifat yang lebih mudah cemas dan gelisah. Ada beban pikiran yang mereka alami selama ini, mereka berfikiran bahwa mereka sudah semakin tua dan menganggap bahwa mereka sudah semakin mendekati ajal. Beban pikiran ini selalu terbawa saat lansia berada di tempat 
tidur. Ketakutan-ketakutan inilah yang nantinya akan menjadikan beban pikiran pada lansia semakin berat. Meningkatnya tingkat insomnia ini juga bisa disebabkan karena pengetahuan yang dimiliki oleh lansia masih kurang, sehingga lansia tidak mengetahui cara mengatasi insomnianya.

Dengan berolahraga akan merangsang kelenjar pineal untuk mensekresi serotonin dan melatonin (berperan dalam mengontrol irama sirkandian, sekresinya terutama pada malam hari yang berhubungan dengan rasa mengantuk). ${ }^{5}$ Pelaksanaan senam bugar lansia secara teratur seminggu tiga kali dapat membuat pikiran lebih tenang dimana tidak ada perasaan gelisah ataupun stress sehingga lanjut usia lebih mudah dalam berkonsentrasi serta merasa gembira. Dalam kondisi rileks, lansia akan mudah dalam memenuhi kebutuhan tidurnya. ${ }^{11} \mathrm{Hal}$ ini sesuai dengan pernyataan responden yang menyatakan bahwa mereka merasa pikirannya lebih tenang sehingga tidak mengalami stress, tubuh menjadi rileks dan tidak merasa kelelahan lagi setelah bangun tidur, serta tidur semakin nyenyak. Hal ini disebabkan oleh pelaksanaan senam lansia yang penulis lakukan benar dan tepat yaitu 6 kali senam lansia dalam 2 minggu. Kegiatan senam lansia yang penulis berikan ini merupakan kegiatan senam lansia yang baru pertama kali lansia lakukan. Sejauh ini di panti tempat lansia tinggal tidak pernah ada program kegiatan senam lansia secara rutin. Keberhasilan senam lansia yang telah penulis lakukan pada responden tidak lepas dari kepatuhan responden dalam mengikuti senam lansia setiap pagi selama 2 minggu, serta responden juga harus benar-benar percaya bahwa tindakan ini dapat membantu proses penurunan tingkat insomnia yang mereka alami.

Di sisi lain, dukungan dan kepercayaan dari pengurus panti terhadap penyembuhan bagi anggota panti juga sangat besar di mana pengurus panti kooperatif dengan tindakan yang dilakukan oleh peneliti. Pendapat tersebut juga diperkuat oleh Rahayu dalam Mahardika (2012) yang mengatakan bahwa senam lansia dapat merangsang penurunan aktivitas saraf simpatis dan peningkatan aktivitas parasimpatis yang berpengaruh pada penurunan hormon adrenalin, norepinefrin dan katekolamin serta vasodilatasi pada pembuluh darah yang mengakibatkan transpor oksigen ke seluruh tubuh terutama otak lancar. Pada kondisi ini akan meningkatkan relaksasi lansia. ${ }^{8}$

Selain itu sekresi melatonin yang optimal dan pengaruh beta endhorphin membantu peningkatan pemenuhan kebutuhan tidur lansia. Namun keberhasilan ini tidak lepas dari kepatuhan lansia secara rutin mengikuti senam lansia selama dua minggu. Dengan dilakukanya senam lansia, perubahan tingkat insomnia yang lansia alami beragam. Tingkat insomnia yang paling banyak adalah tingkat insomnia dalam kategori ringan, yang semula tingkat insomnia ringan sebelum dilakukan senam lansia berjumlah 2 orang menjadi 6 orang setelah dilakukan senam lansia, dan terdapat kategori tidak ada insomnia yang berjumlah 2 orang setelah dilakukan senam lansia. Hal ini menunjukkan bahwa ada perubahan tingkat insomnia ke arah yang lebih baik setelah dilakukan senam lansia. Sehingga secara perlahan senam lansia akan digunakan para responden sebagai terapi alternatif non farmakologi dalam menurunkan tingkat insomnia yang mereka alami. Dengan perkataan lain para responden diharapkan mampu melakukan senam lansia secara mandiri serta dapat membantu para penderita insomnia yang lain dalam memberikan informasi tentang alternatif non farmakologi senam lansia dalam menurunkan tingkat insomnia yang mana erat kaitannya dalam mengurangi angka kejadian insomnia yang setiap tahunnya meningkat.

\section{Kesimpulan}

Penelitian ini menyimpulkan adanya perbedaan rata-rata tingkat insomnia sebelum dan sesudah intervensi senam lansia.

\section{Ucapan Terima Kasih}

Penulis beserta tim penelitian mengucapkan terima kasih kepada Panti Jompo Karya Kasih Medan, Pimpinan Institusi dan jajarannya Fakultas Kedokteran Universitas Prima Indonesia

\section{Referensi}

1. Tamher S, Noorkasiani. Kesehatan Usia Lanjut dengan Pendekatan Asuhan Keperawatan. Salemba Medika. Jakarta. 2009. 
2. Kementerian Kesehatan. Buletin Lansia: Gambaran Kesehatan Lanjut Usia di Indonesia. Kementerian Kesehatan. Jakarta. 2013.

3. Stanley M, Beare PG. Buku Ajar Keperawatan Gerontik Edisi 2. Penerbit EGC. Jakarta. 2007.

4. Retnaningsih D, Apriana R, Mariyati. Pengaruh Senam Lansia Terhadap Skala Insomnia Pada Lansia di Panti Wredha Harapan Ibu Ngaliyan Kota Semarang. Jurnal Ners Widya Husada Vol. 2 No.1: 2015.

5. Sumedi T, Wahyudi, Kuswati A. Pengaruh Senam Lansia terhadap Penurunan Skala Insomnia Ada Lansia di Panti Wredha Dewanata Cilacap. Jurnal Keperawatan Soedirman Vol. 05 No. 1: 2010.

6. Danirmala D, Arian P. Angka Kejadian Insomnias Pada Lansia di Panti Tresna Wer-dha Wana Seraya Denpasar Bali Tahun 2015. Jurnal Medika Udayana Vol.8 No.1: 2019.

7. Nugroho W. Keperawatan Gerontik dan Geriatrik. Penerbit Buku Kedokteran EGC. Jakarta. 2010.

8. Mahardika J, Haryanto J, Bakar A. Hubungan Keteraturan Mengikuti Senam Lansia Dan Kebutuhan Tidur Lansia di UPT PSLU Pasuruan di Babat Lamongan. Indonesian Journal of Community Health Nursing Vol.1 No.1: 2012.

9. Hidayat BUA. Hubungan Tingkat Stres Dengan Kejadian Insomnia Pada Mahasiswa Program Studi IImu Keperawatan Universitas Diponegoro. Program Studi Keperawatan Fakultas Kedokteran Universitas Diponegoro. 2011.

10. Susanti L. Faktor-Faktor Yang Mempengaruhi Kejadian Insomnia di Poliklinik Saraf RS DR. M. Djamil Padang. Jurnal Kesehatan Andalas Vol. 4 No. 3: 2015.

11. Sari E, Halawa A. Senam Lansia Terhadap Tingkat Insomnia Pada Lansia di Panti Werdha Usia Anugerah Surabaya. Seminar Nasional dan Workshop Publikasi Ilmiah "Strategi Pengembangan Profesionalisme Perawat Melalui Peningkatan Kualitas Pendidikan dan Publikasi IImiah". STIKES RS Baptis Kediri. 2017. 